\title{
Groundwater pollution in the Mesta River terrace caused by Eleshnitsa tailings pond - current status
}

\section{Замърсяване на подземните води в терасата на река Места от хвостохранилище „Елешница“ - съвременно състояние}

\author{
Nikolay Stoyanov ${ }^{1}$, Stefan Dimovski', Sava Kolev ${ }^{2}$ \\ Николай Стоянов ${ }^{1}$, Стефан Димовски ${ }^{1}$ Сава Колев ${ }^{2}$ \\ ${ }^{1}$ Faculty of Geology and Exploration, University of Mining and Geology "St. Ivan Rilski”, 1700 Sofia, Bulgaria; \\ E-mails: nts@mgu.bg; dimovski@mgu.bg; \\ ${ }^{2}$ Geological Institute, BAS, Acad. G. Bonchev str., bl. 24, Sofia; E-mail: sava_kolev@geology.bas.bg.
}

\begin{abstract}
Even after the implementation of eco-protective measures, the Eleshnitsa tailings pond continues to contaminate the Quaternary aquifer, formed in the alluvial deposits of Mesta River. A three-dimensional model of mass transport of selected key pollutants is developed on the basis of hydrochemical studies, geophysical surveys, and processing and systematization of monitoring data. The spread and degree of contamination in the Quaternary aquifer are estimated.
\end{abstract}

Keywords: groundwater pollution, geoecology, hydrogeological model, old uranium mining, Eleshnitsa tailings pond.

\section{Introduction}

The second half of the twentieth century in Bulgaria was marked by a very rapid development of the uranium mining and processing industry, which is the reason for intensive water and soil contamination in the areas of the performed extraction activities. Subsequently, the cessation of this sector of national economy in 1992 did not solve the occurred environmental problems. The closed uranium mines, the old geotechnical installations and facilities, the tailings ponds, as well as the polluted production sites represent one very significant source of contamination, which will continue its negative impact in the coming decades. Such a hotspot and subject of our study is the tailings pond of one of the largest in the past uranium extraction industrial complexes in the area of Eleshnitsa deposit, falling within the catchment area of the Mesta River.

\section{Characteristics of the source of pollution}

Uranium mining in the area of Eleshnitsa deposit was carried out in the period 1955/1992, and in 1965 an ore processing plant was built in the region. The
Eleshnitsa tailings pond has been exploited since 1969. It is located at the upper course of Valche Dere River, a left tributary of Mesta River. According to Kolev (2019) in the tailings pond, besides radioactive materials, various chemical wastes are deposited - sulfuric acid, carbonates, bicarbonates, manganese oxide, potassium permanganate, nitrites, kerosene and other reagents used in the process of crushing, reduction and leaching of uranium ore in order to obtain uranium concentrate, as well as the accompanying heavy metals. Currently, the tailings contain about 9 million tons of hydrometallurgical waste, including about 730 tons of uranium. The long-term monitoring shows that tailings pond leachate contains large amounts of sulphate ions $\left(\mathrm{SO}_{4}\right)$, various natural radionuclides $-{ }^{238} \mathrm{U},{ }^{230} \mathrm{Th},{ }^{226} \mathrm{Ra},{ }^{222} \mathrm{Rn},{ }^{218} \mathrm{Po}$, ${ }^{214} \mathrm{~Pb},{ }^{214} \mathrm{Bi},{ }^{214} \mathrm{Po},{ }^{210} \mathrm{Bi}$, and a number of heavy metals - Fe, $\mathrm{Cu}, \mathrm{Mo}, \mathrm{Co}, \mathrm{Ni}, \mathrm{Zn}, \mathrm{Cr}, \mathrm{As}, \mathrm{Hg}, \mathrm{Mn}$, etc. In the period 2002/2005, the tailings pond is rehabilitated and a wastewater treatment plant is built for removal of heavy metals, the waters from which are discharged in the Valche Dere River. Data from subsequent research activities (Kolev et al., 2014; Kolev, 2016) show that even after the implementation of 
eco-protective measures, the tailings pond continues to contaminate not only Valche Dere River, but also groundwater in the river terrace deposits, where high sulfate concentrations are observed.

\section{Data on surface water and groundwater contamination}

Main source of water pollution in the study area is the tailings pond. The heavily contaminated waters flowing out of it are completely drained in Valche Dere River, where waters coming out of the treatment plant are also discharged. Data from the systematic observations of the composition and quality of water in the Valche Dere River at a monitoring point situated just before its confluence with the Mesta River (Kolev, 2019) show that in the period 1963/2019 increased concentrations of sulfate ions $\left(\mathrm{SO}_{4}\right)$, uranium and radium $\left({ }^{226} \mathrm{Ra}\right)$ are registered (Fig. 1). Their values, especially before the tailings pond reclamation, significantly exceed the natural background, as well as the standards defined in Regulation No. 9 that sets out the requirements for the quality of water intended for drinking and household purposes in Bulgaria. During this period, the concentration of radium most often varies from 1.5 to 16 times above the limit, the concentration of uranium - from 1.3 to 12 times above the limit, and the concentration of sulfates - from 1.6 to 7.5 times above the limit. In the last 5-10 years, the concentrations of the three pollutants fall to values close to the drinking water standards but remain well above the natural background.

The first recipient of the polluted waters of Valche Dere River is the Quaternary aquifer, formed in the alluvial deposits of the Mesta River and its tributaries. Over the last 50 years, Valche Dere River, in its lower course, represents a permanent and very intensive source of groundwater contamination, which is predetermined by the morphology of the terrain and the high permeability of the river bed. This concept is confirmed by data from non-systematic observations in a monitoring well, constructed in the river terrace (Fig. 1). In this monitoring well, located $20 \mathrm{~m}$ away from the river bank, in the period 2002/2020 the registered concentrations of $\mathrm{SO}_{4}$ are most often in the range from 100 to $1300 \mathrm{mg} / \mathrm{L}$, average concentration around $460 \mathrm{mg} / \mathrm{L}$, of $\mathrm{U}-$ from 29 to $435 \mu \mathrm{g} / \mathrm{L}$, average concentration around $217 \mu \mathrm{g} / \mathrm{L}$, and of ${ }^{226} \mathrm{Ra}$ - from 51 to $190 \mathrm{mBq} / \mathrm{L}$, average concentration around $102 \mathrm{mBq} / \mathrm{L}$. Additional data on groundwater contamination in the river terrace are not found.

According to the available information from the non-systematic monitoring performed in the period 1992/2019, Eleshnitsa tailings pond causes a negligible or completely nonexistent pollution to Mesta River. The concentrations of $\mathrm{SO}_{4}$ established after the confluence with Valche Dere River are most often in the range from 10.6 to $48.6 \mathrm{mg} / \mathrm{L}$, average concentration around $30 \mathrm{mg} / \mathrm{L}$, of $\mathrm{U}$ - from 6 to $56 \mu \mathrm{g} / \mathrm{L}$, average concentration around $30 \mu \mathrm{g} / \mathrm{L}$, and of ${ }^{226} \mathrm{Ra}-$

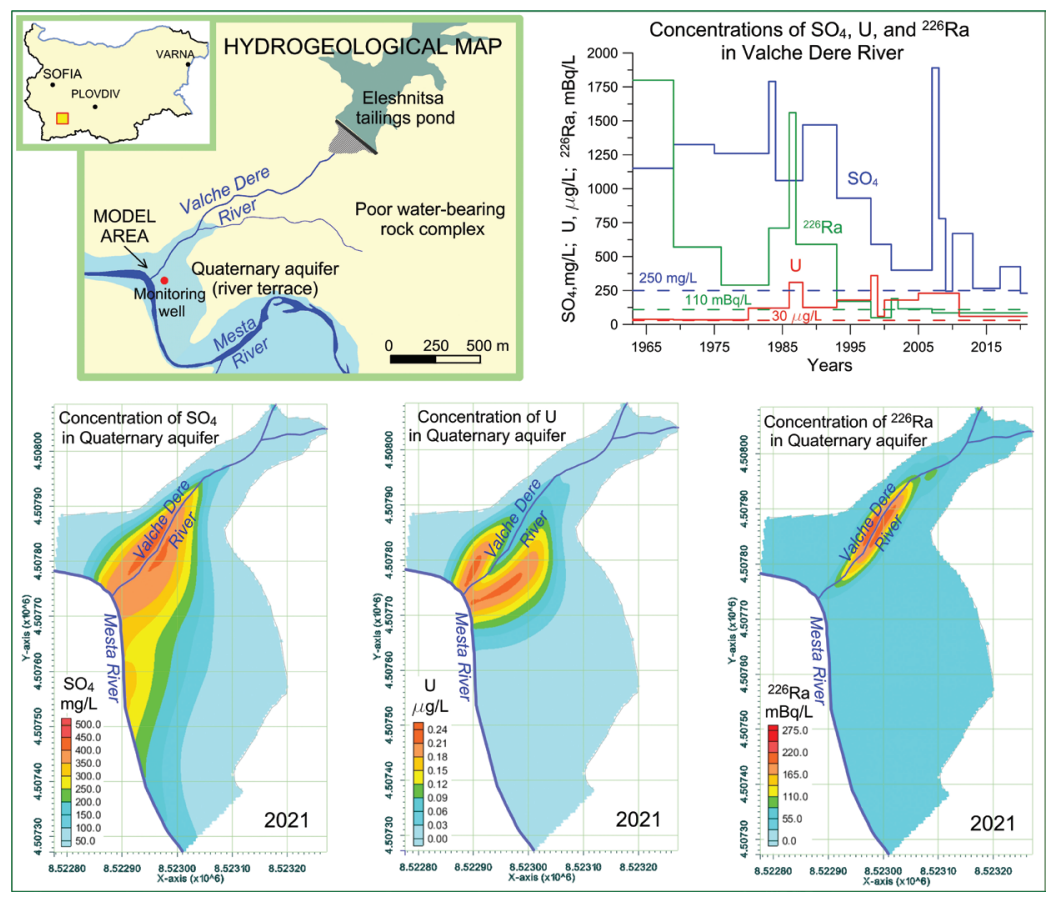

Fig. 1. Left, hydrogeological map of the region of Eleshnitsa tailings pond; right, monitoring data on concentrations of selected key pollutants in Valche Dere River (the dotted lines show the maximum permissible limits set in Regulation No. 9); bottom, model solutions - maps illustrating the spread and degree of contamination in the Quaternary aquifer 
from 20 to $100 \mathrm{mBq} / \mathrm{L}$, average concentration around $50 \mathrm{mBq} / \mathrm{L}$.

\section{Methodology and tools for assessment of groundwater pollution in the river terrace}

The quantitative assessment of the extent and degree of groundwater contamination in the river terrace is made on the basis of a detailed study conducted in the period 2020/2021 in the area of the Eleshnitsa tailings pond. The study includes: (i) processing and systematization of monitoring data on changes in the composition of surface waters in Valche Dere River and Mesta River and of groundwater in the monitoring well; (ii) field and laboratory studies of the chemical composition of waters and soils; (iii) geophysical surveys, applying the ERT method, down to a depth of 40-45 m; (iv) mathematical threedimensional model of contamination in the Quaternary aquifer.

A general concept for the hydrogeological and technogenic conditions, the main factors, and the mechanism of groundwater pollution in the river terrace is developed. On this basis, using the computer programs Modflow and MT3D-MS (Anderson et al., 2015; Stoyanov, 2019), a three-dimensional model of the mass transport of pollutants from the Valche Dere River into the potentially endangered part of the Quaternary aquifer is developed. The model is utilized for studying the behavior of key pollutants $-\mathrm{SO}_{4}, \mathrm{U}$ and ${ }^{226} \mathrm{Ra}$. The applied approach has been approbated in past studies evaluating the risk of pollution in the area of Kozlodui NPP, uranium deposit Momino, Ogosta River valley, etc. (Stoyanov, 2012, 2019; Stoyanov et al., 2018; Gerginov et al., 2020). The calculation scheme takes into account the processes of convection, reversible and irreversible elimination (sorption-desorption, ion exchange, precipitation and decay), dispersion, diffusion and mixing. The model area covers part of the right-bank terrace of Mesta River (Fig. 1). The Quaternary aquifer is composed of gravels and sands with a total thickness of $8-15 \mathrm{~m}$ and is modeled as a three-dimensional object. The hydraulic conductivity set in the model is determined in situ, and the diffusion coefficient, the dispersivity and the distribution coefficients for each pollutant are accepted according to published data taking into account the lithological characteristics and the granulometric composition of the porous medium (Gelhar et al., 1992; Spitz, Moreno, 1996; Stoyanov, 2019). The concentrations of pollutants in Valche Dere River are set as independent variables according to the line charts presented in Fig. 1.

\section{Results}

The maps obtained with the mathematical model are presented in Fig. 1. They illustrate the spread and degree of contamination in the Quaternary aquifer by 2021 . The $\mathrm{SO}_{4}$ map outlines the maximum range of the contaminated region, and the $\mathrm{U}$ and ${ }^{226} \mathrm{Ra}$ maps mark the area with the most intense pollution, where the concentration of conventional, toxic and radioactive contaminants is highest.

With the developed model it is possible not only to trace in historical aspect the processes of pollution in the Quaternary aquifer caused by Eleshnitsa tailings pond, but also to predict their development taking into account the results of the performed water quality monitoring.

Acknowledgement: This work has been carried out in the framework of the National Science Program "Environmental Protection and Reduction of Risks of Adverse Events and Natural Disasters", approved by the Resolution of the Council of Ministers № 577/17.08.2018 and supported by the Ministry of Education and Science (MES) of Bulgaria (Agreement № DO-230/06-12-2018).

\section{References}

Anderson M., W. Woessner, R. Hunt. 2015. Applied Groundwater Modeling: Simulation of Flow and Advective Transport. Elsevier Academic press, 2nd ed., 720 p.; https://doi. org/10.1016/C2009-0-21563-7.

Gelhar L., C. Welty, K. Rehfeldt. 1992. A critical review of data on field-scale dispersion in aquifers. - Water Resour. Res., 28, 7, 1955-1974; https://doi.org/10.1029/92WR00607.

Gerginov, P., D. Antonov, A. Benderev, V. Stoyanova, T. Kotsev. 2020. Analysis and prognosis of the aqueous migration of arsenic based on complex study of Ogosta river valley's hydrogeological elements (at specific floodplain site). - C. R. Acad. bulg. Sci., 73, 10, 1409-1415; https:// doi.org/10.7546/CRABS.2020.10.10.

Kolev, S. 2016. Surface-groundwater interaction at the region of Vulche Dere, downstream of "Eleshnitsa" tailing pond. - Proc. National Conf. Bulg. Geol. Soc. Geosciences 2016, 135-136 (in Bulgarian with English abstract).

Kolev, S. 2019. Current State and Prediction of Radionuclide Contamination of Groundwater and Surface Water in the Region of the Eleshnitsa Uranium Mine. PhD Thesis, Sofia, Geol. Inst. BAS, COBISS.BG-ID 1561156308, 120 p.; https://plus.bg.cobiss.net/opac7/bib/1561156308\#full (in Bulgarian).

Kolev, S., N. van Meir, K. Ivanova. 2014. Assessment of the current state of radionuclides and metals content in the surface and groundwater at the region of Eleshnitsa former uranium mine. - Radiation Protection J., 2, 35-42.

Spitz, K., J. Moreno. 1996. A Practical Guide to Groundwater and Solute Modeling. New York, John Wiley \& Sons, 460 p.

Stoyanov, N. 2012. Model studies estimating the risk of a possible pollution in geological basis and groundwater caused by the designed national disposal facility for storage of radioactive waste in the region of NPS "Kozlodui"-Ann. Univ. Mining and Geol., 55, 1-Geol., 140-145 (in Bulgarian with English abstract).

Stoyanov, N. 2019. Mathematical Modeling in Hydrogeology. Numerical 3D Models Using Finite Difference Method. Sofia, Publ. House V. Nedkov, 246 p. (in Bulgarian).

Stoyanov, N., S. Kolev, V. Petrov. 2018. Prognosis of contaminants mass transport in groundwater after cessation of uranium mining in Momino deposit (South Bulgaria) - Proc. 18th Intern. Multidisciplinary Sci. Ceoconference SGEM 2018, 18, 12, 593-600; https://doi.org/10.5593/sgem2018/1.2. 